\title{
Človek kot iskalec (ljubitelj) modrosti pred izzivi sodobnosti
}

\author{
Man as a Seeker (Lover) of Wisdom \\ Facing the Challenges of Modernity
}

Značilnost človeškega duha je, da se ne zadovolji s tem, kar vidi, zazna in izkusi, temveč neprestano stremi po novem, popolnejšem, globljem (spo)znanju. Sprašuje se po izvoru stvari in njihovem smislu. Človek se kot misleče bitje sprašuje, kako to, da sploh kaj je, in ne rajši nič (G. W. Leibniz). Kako to, da sploh kaj je, ko pa bi lahko ne bilo? Kako to, da sem, ko pa bi me lahko ne bilo? Vsa ta vprašanja nas vodijo do vprašanja začetka, izvora. Ta iskanja odstirajo skrivnostnost ustvarjenosti prigodnega stvarstva ter kažejo na zastonjskost podarjenosti bivanja. Ena od nalog filozofije je v iskanju odgovorov na temeljna vprašanja človeka (eksistencialna vprašanja) in sveta ter njunega izvora. Naloga filozofije je iskanje resnice o celoti, iskanje resničnega znanja. Po svoji definiciji je filozofija univerzalna znanost, prizadevanje človeškega uma, da odkrije bistvo in končne vzroke vsega, kar obstaja. Na splošno je naloga filozofije prepoznavanje konceptualnih distinkcij in oblikovanje teoretskih diskurzov, stvari in pojave mora znati razložiti v medsebojni vzročni povezavi. Filozofija mora znati postavljati prava vprašanja, dojeti in opredeliti mora, kaj se v svetu dogaja in zakaj se dogaja, kar se dogaja, prepoznati, kam lahko to vodi, in to razumsko utemeljiti.

V času, ko smo ujeti v novi (četrti) val koronakrize, ko se soočamo z globalno okoljsko krizo, naraščajočimi razlikami med bogatimi in revnimi, razvitimi in manj razvitimi, ko smo priča naraščajoči krizi na političnem, 
kulturnem in širšem družbenem področju, se vse glasneje kaže potreba, da znanost spregovori s svojimi argumenti in ponudi ustrezne trajnostne rešitve. Danes smo namreč priča težavi, ki izhaja iz razlike med vsakdanjo in znanstveno resnico. Védenje (ki je pravzaprav mnenje, mnenje pa ni znanost) ne temelji na znanstvenih dejstvih, ki so plod raziskav in analiz, temveč na prepričanju, da je to, kar človek misli, da ve, razumljeno kot dejstvo. Iz tega izhaja največ razlik v pojmovanju sodobnih pojavov, družbenih vlog, posledično tudi težav pri pojmovanju človeka, človekove svobode ter njegovih pravic in dolžnosti. Ena od nalog filozofije je, da preverja veljavnost in pomen govorice ter razkriva predsodke in vnašanje pomenov, ki ne temeljijo na znanstvenih podlagah.

Tako predstavlja sodobnost izziv (poziv!) in priložnost za humanistiko, posebej teologijo in filozofijo, da pomagata analizirati in razumeti sodobni trenutek in pokazati tudi na to, da je človek kljub ujetosti v sedanji prostor in čas bitje, ki zaradi svoje transcendence vso tukajšnjost presega. Človek kot oseba presega ta svet in presega svojo naravno določenost. Človek se lahko nad oboje dviga, kar kaže na človekovo transcendenco, ki izhaja iz njegove duhovnosti. Ko človek kot transcendirajoče bitje spoznava, da je zgolj prigodno bitje in da nima nikakršnih zaslug za to, da je, in ko doumeva, da je samemu sebi podarjen in pozvan od nečesa (nekoga), ki je onstran, ki je Drugi (A. Stres), to po eni strani zrelativizira težo sedanjosti, po drugi strani pa prebuja odgovornost, da človek svojo podarjenost uresničuje; da uresničuje svoje poslanstvo, ki mu je s podarjenostjo bivanja naloženo ali zadano, da ga uresniči. Vsak človek je povabljen, da svoje življenje uresničuje v skladu s svojo poklicanostjo oz. izvoljenostjo (svetopisemska poklicanost po imenu oz. izvoljenost človeka kot osebe), s tem pa ostaja zvest samemu sebi in sledi smislu svojega življenja.

Človek se nikoli ne more uresničevati ločeno od drugih, prav tako ne more težiti k dobremu zgolj kot posameznik. Posameznik in njegova identiteta se vedno določata z zavezanostjo drugim in okolju, v katerem živi in deluje, ter na ozadju moralnega obzorja, kateremu pripada. Smiselnost človekovega bivanja se kaže ne toliko v samouresničevanju, temveč v izstopanju iz zagledanosti vase, $v$ pozabi nase in v pozabi na svoje egoistične želje. Smiselnost bivanja se kaže $v$ preseganju samega sebe in $v$ predanosti nekomu ali nečemu, kar človeka presega (V. Frankl). Predanost in odprtost za D/ 
drugega omogoča pogled preko tragičnosti sedanjega trenutka in odpira človeka za solidarnost.

Možnost odprtosti za D/drugega, odprtost za stiske in potrebe drugega, čut za bližnjega in skupno dobro se kažejo kot tiste razpoložljivosti človeka, ki so v sodobnem negotovem času na preizkušnji. Ko se zdi, da se je človeštvo večinsko opredelilo za hiter razvoj, se hkrati vse bolj zaveda potrebe po etičnih normah, ki bodo omogočale življenje, vredno človeka in njegovega dostojanstva, ter življenje v sožitju s celotnim stvarstvom (J. Trontelj). Na preizkušnji sta solidarnost in dialog. Solidarnost je pomembna, saj omogoča, da neka skupnost obstoji in preživi, solidarnost je tista vez človeškosti, ki ne spregleda niti najbolj obrobnega, osamljenega in zapuščenega.

Zdi se, da je naša družba razklana bolj kot kadarkoli v obdobju naše samostojne države, katere 30. obletnico slavimo v letošnjem letu. Pestijo nas težave mladostniške zaletavosti in nezrelosti tako na političnem parketu kot na ulici, manjka modrosti in politične volje, da bi se ukvarjali z resničnimi problemi, in ne s parcialnimi strankarskimi interesi ter krčevitim, s pouličnim besednjakom opremljenim bojem za oblast. Treba je prebuditi etično zavest posameznika in družbe. Zavest, da je glavno prizadevanje, glavna naloga politike, ki pravzaprav izhaja iz etike, skrb za skupno dobro, prizadevanje za pravičnost in pravično porazdelitev dobrin. Za takšno politično kulturo so potrebni ljudje, ki bodo ustrezno izobraženi in vzgojeni, ali kot pravi Aristotel, tisti, ki bodo z že privzgojeno osnovo plemenitosti poslušali predavanja o plemenitosti in poštenosti, skratka o politični znanosti (Nikomahova etika) in nato to tudi udejanjali v osebnem življenju in življenju skupnosti, skrbeli za harmonično sobivanje ljudi in pospeševali prizadevanja za skupno dobro.

Razumeti je treba, da se življenje spreminja, močno ga spreminja tudi soočanje s koronakrizo in z njo poveznimi ukrepi, zato je razumljivo, da doživlja družba krizo, da je v krizi človek in da so stiske, ki jih človek ob tem doživlja, resnične. Zato potrebuje sodobni čas modrih ljudi, ki bodo v teh razmerah spodbujali k solidarnosti, strpnosti, ki bodo pripravljeni pomagati in bodo spodbujali tudi druge, da si je treba pomagati. Sodobni čas potrebuje razumnih in sočutnih ljudi, ki bodo sposobni ohranjati in negovati človeškost in odgovornost. Vlivati je treba upanje in vračati vero 
v dobroto, spodbujati k sočutju in solidarnosti ter medsebojni pomoči. Zaupati moramo, da sta tudi danes, ko sta na preizkušnji kolektivni zdrav razum in solidarnost, možna in mogoča edinost in dialog. Treba je prisluhniti drugemu in poskušati razumeti vso raznolikost, pri čemer na račun različnosti in drugačnosti ne moremo postavljali pod vprašaj osnovnih civilizacijskih norm in dostojanstva človekovega življenja ali celo izpostavljati tveganju usode svojega bližnjega in svoje lastne.

Naloga filozofije je, da pomaga razumeti to dogajanje, da pomaga razumeti težave današnjega sveta in človeka ter mu ponuditi konkretne odgovore na vprašanje, kako naj človek v teh razmerah živi. Filozofija namreč vključuje dva vidika: teoretičnega in praktičnega. V teoretičnem smislu lahko govorimo o filozofiji kot o sistemu resnic oziroma o urejenem nizu stavkov, ki izražajo določen pomen. V praksi pa se filozofija nanaša na človeško delovanje in odgovarja na vprašanje: kako živeti? Glede obeh vidikov je prehodila filozofija skozi zgodovino različne poti: včasih je bila bolj teoretična, drugič bolj praktična. In prav današnji čas, v katerem se zdi, da se ruši ustaljeni red in način življenja, da se izgublja zaupanje v demokracijo, v znanost in razum, da se izgublja zaupanje v človeka in izgubljajo moč avtoritete, ki urejajo posamezna področja človekovega življenja, ko pojem skupnega dobra izginja z obzorja mišljenja in življenja sodobnega človeka, prav današnji čas potrebuje konkretnih napotkov, kako živeti.

Zato se pri iskanju skupnih poti in konkretnih rešitev iz sodobnih stisk kaže filozofija dialoga (M. Buber) kot tista, ki bi mogla ustrezno odgovarjati na potrebe sodobnega človeka, ki si želi biti slišan, ki želi izraziti svoj strah, ranljivost in odvisnost od drugih. Prav dialog je tisti prostor, ki omogoča, da se drug drugemu odpremo in prisluhnemo resnici, ki jo človek nosi v sebi. Filozofija dialoga lahko pomaga sodobnemu času in človeku pri streznitvi od senc, ki se zdijo resničnost, pri rešitvi iz okov nevednosti in lažne znanosti, pri osvoboditvi od lastnih principov, predsodkov in mnenj. Dialog je pot do resnice; pot, ki lahko povrne zaupanje v razum. Če je bil novi vek zaznamovan z vero v razum, a se je ta izkazal za varljivega v trenutku, ko ga je človek postavil na piedestal vsemogočnega, se v sodobnem času kaže potreba po vrnitvi vere šibkemu razumu, da bo prevzet od Božanskega logosa, sposoben odprtosti za resnico. 
Dialog ne pomeni preprostega komuniciranja niti spretnosti retorične prepričljivosti, temveč spada, kot pravi Dostojevski, v red ljubezni. To pa pomeni popolnoma nov pogled, radikalen preobrat $\mathrm{v}$ pojmovanju dialoškosti, kjer je dialoškost predstavljena kot koordinatni sistem ustvarjalnosti. Bistvo dialoga, kot se pokaže že s Sokratom, ni toliko v vsebini pogovora, temveč v osebi: kdo se pogovarja in kakšen ta človek je. Lahko bi rekli, da gre za neke vrste bujenje moralne zavesti sogovornika, kar je tudi del Sokratovega poslanstva: spodbujati sogovornike k razmisleku in skrbi za dušo. (P. Hadot) To poslanstvo uresničuje Sokrat do poslednjega dne svojega življenja, kar je razvidno iz Platonovega zapisa Sokratovega zagovora v sodnem procesu 1. 399 pr. Kr.: »Tedaj, ko hodim okrog, namreč ne delam nič drugega kot to, da vas neprestano spodbujam, mlajše in starejše, da si ne prizadevajte najprej in tako vneto za telesa in premoženje, temveč za to, da bi bila (vaša) duša čim boljša ..." (Apologija)

Dialoga se moramo ponovno učiti tudi danes in si ponovno priklicati v zavest, da je človeškost mogoče živeti samo v odnosu z drugimi (M. Buber). K temu nas spodbuja tudi ta številka revije Edinost in dialog. Avtorji prispevkov v svojih analizah, komentarjih in znanstvenih razpravah odstirajo vpogled $v$ bistvo, razsežnosti in pomen dialoga (M. Pevec Rozman, S. Kristovič in U. Zabukovec), predstavijo etiko in načela prevajanja mag. M. Holca (S. Skralovnik) in njegovo analizo filološko-lingvističnega komentarja Visoke pesmi (A. Tedeško). O problematiki prevajanja islamskih virov ter Korana in hadisov v slovenski jezik pišeta M. J. Osredkar in A. Kranjc, C. Oblonšek pa izpostavi že dalj časa prisotno težavo, ki se kaže v razpetosti med ohranjanjem zvestobe tradiciji Cerkvi in spoštovanjem načel obhajanja liturgije, kot jo prinaša drugi vatikanski cerkveni zbor. Z vprašanjem »liturgije« svobodnih Cerkva se kritično soočata E. Budiselić in D. Kraljik. V. Škafar predstavi duhovnika in gorečega pastoralnega delavca Jožeta Vesenjaka, ki velja za enega od pionirjev ekumenskega gibanja na Slovenskem, med drugim je bil tudi urednik ekumenskega zbornika $V$ edinosti, ki je predhodnik sedanje znanstvene revije Edinost in dialog. Isti avtor predstavi poročilo treh govorov papeža Frančiška, ki jih je imel v mesecu septembru 2021 med obiskom na Madžarskem in Slovaškem. Revija prinaša zanimiv etnološki oris o svetem Hieronimu na slovenskih tleh, kakor pričajo redki filološki viri (M. Stanonik), ter na Slovenskem spregledano delo srednjeveškega misleca Lotarija iz Segnija (1161-1216), kasnejšega papeža Inocenca III. (J. Šček). M. Dragnea analizira malikovanje 
in podobe poganov in poganstev $\mathrm{v}$ Pomeraniji v prvi polovici dvanajstega stoletja, F. Križnar pa predstavi podroben pogled in analizo arhivskega zvočnega gradiva opusa skladatelja, violinista in glasbenega teoretika Giuseppeja Tartinija.

V času, ki ga doživljamo kot čas preizkušnje, stiske in tudi strahu pred negotovo prihodnostjo (predvsem zaradi že omenjenega širjenja koronavirusa), v času, ko se morejo in morajo oglasiti humanistične znanosti, se oglaša tudi ta številka revije Edinost in dialog, ki prinaša pravo olajšanje. Teme, ki jih obravnavajo avtorji, namreč vračajo občutek normalnosti, prinašajo upanje in tolažbo, da je mogoče na vso tukajšnjost gledati tudi z drugega zornega kota, z vidika »sub specie aeternitatis«, in na tem obzorju iskati smiselnost, ohranjati človeškost in čut za bližnjega.

Naj bo v prijetno in opogumljajoče branje. 